\title{
Jandi La Surong: Film as a Medium for Transmitting Karo Culture and Tradition
}

\author{
${ }^{1}$ Rangga Saptya Mohamad Permana, ${ }^{2}$ Lilis Puspitasari, ${ }^{3}$ Sri Seti Indriani \\ Universitas Padjadjaran, Indonesia \\ \{rangga.saptya@unpad.ac.id $\left.{ }^{1}\right\}$
}

\begin{abstract}
Viewing from a communication perspective, a film (cinema) is included in the mass communication media. This is because the film fulfills all the characteristics to become a medium of mass communication. One of the functions of mass media is as a cultural transmission media. Jandi La Surong (JLS) is a film by Karo filmmakers who have a mission to revive the Karo culture and tradition which is beginning to fade. This article aims to describe JLS film as a cultural transmission medium for the Karo community. The qualitative-descriptive method was chosen in this research, with data collection techniques in the form of interviews, observation, and literature. The results of the research showed that the transmission of Karo culture and tradition in the JLS film was manifested in the use of the Karo language throughout the film and the emergence of scenes that were thick with Karo culture and traditions, including Bertutur, Erpangir Ku Lau, Gundala-gundala, Ndikar, and Satur.
\end{abstract}

Keywords: Karo, Culture And Tradition, JLS

\section{Introduction}

Films can be viewed as the work of human creations that contain high aesthetic elements, or can also be seen as a medium of communication, where films can be used as a medium to channel and disseminate messages from filmmakers to the public. In another perspective, we can say that we view films from a communication perspective, because films are included in one form of mass media. So, if a producer produces a film to convey certain messages through the film he produces, then he has made mass communication.

The simplest definition of mass communication is stated by Bittner [1], mass communication is a message communicated through mass media to a large number of people. Some characteristics of mass communication include general messages, communicating anonymously, heterogeneous and spread, and are one-way. Dominick revealed that one of the functions of mass communication for the community was the spread of values, or also called the socialization function. Socialization refers to the way in which individuals adopt group behavior and values. The mass media that represents the picture of society is watched, heard and read. The mass media shows us how they act and what they expect. In other words, the media represent us with the role model that we observe and hope to emulate [1].

Related to the socialization function, Vivian added that mass media had a big role in bringing children into the community. This process of socialization is important to maintain cultural values, but some people worry that negative impacts will arise if the media reports and describes 
unwanted behaviors and attitudes, such as violence and racism [2]. Meanwhile, Effendy said that mass communication also had an educational function, because mass media presents many things that are educational in nature. One way to educate the mass media is through teaching values, ethics, and the rules that apply to the audience. The mass media does this through dramas, stories, discussions, and articles. All of these situations, values that must be followed by the community, are not disclosed directly but are visualized by scenes that should be carried out by the community [1]. The mass media also unites the community by giving messages received together [2].

Specifically, in addition to the means of transmitting culture, mass media also contributes to transmitting historical values in society. Mass media transmits cultural values through history. The previous generation speaks to us through the mass media, mostly in the form of books, and we also unconsciously, talk to future generations through the mass media. The mass media also spreads the values and ideas that exist in their respective times [2]. This is in line with Wood's statement which says that mass media brings images and stories that contribute to an awareness of identity, while at the same time forming trust and value [3]. Furthermore, Haviland also states that sharing a number of perceptions and behaviors, members of a culture can also share their common cultural identity. This cultural identity results in a situation where members of each culture know themselves and their cultural traditions are different from others and the traditions of others [3].

Film, where mass media is the dominant form of visual mass communication in this part of the world. One of the media models to explain mass media is to divide the media into hot and cold categories. According to McLuhan, hot media is high-definition communication that provides complete sensory data that can be accepted by the human senses; in using this media the audience is not required to use the power of his imagination, or in other words, very little imagination is needed. Thus, audience participation in hot media is very low because the meaning of the information received by the audience is really complete and clear [4].

Cold media is a low-definition media that requires a large audience participation, in other words, cold media is low-definition communication that requires active participation from viewers, listeners, or readers. There is not much that this type of media can provide to the audience, and the audience must fulfill things that cold media does not provide for themselves. The audience must create meaning through his senses and imaginatively involve him.

Does the film include hot or cold media? According to Vivian, in some ways, films are like televisions, with visual and audio components. But there are essential differences. Movies (cinema/widescreen) involve the audience completely. Large screens help audience to give full attention to the film. Closed and dark theater spaces can also reduce outside interference. In the hot-cold continuum, movies are categorized as hot. Then how is the film being played on television? Films are included as cold media [2].

The film is not only seen as a mere mass media but it is also seen as a business institution. According to Dominick, the film industry is a business industry. This predicate has shifted the notion of people who still believe that film is a work of art, produced creatively and fulfilling the imagination of people who aim to obtain a perfect aesthetic (beauty). Although in reality, it is a form of art, the film industry is a business that provides benefits, sometimes a money machine that often, for the sake of money, comes out of the artistic rules of the film itself [1].

Effendy said, like television, the purpose of audiences watching films was primarily to get entertainment. But films can contain informative and educative functions, even persuasive. This is in line with the national film mission (in Indonesia) since 1979, that aside from being an entertainment media, national films can be used as educational media for fostering the younger generation in the framework of nation and character building [1]. The educational function can 
be achieved if national film producers produce objective historical films or documentaries and films that are balanced from everyday life.

One of North Sumatra's local films that will air in the networked cinema is Jandi La Surong (JLS). which literally means "promises that are not kept". This film is produced by the Karo local production house (PH), namely JLAS Production. The production stage has cost 600 million rupiahs. The film, directed by Creesenda Tenori P. Sembiring or better known as Ori Semloko, is one of the Karo filmmakers active in the North Sumatra (Sumut) film industry, based on the same novel written by M. Tempel Tarigan, one of Karo figures. This film tells about the romance experienced by M. Tempel Tarigan with a girl, where he could not keep his promise to that girl. The film is set in the 1960s and takes place in several areas in North Sumatra Province and in the Special Capital Region of Jakarta. JLS is promoted through social media (Facebook and Instagram), local mass media, and outdoor media such as posters, banners, and banners.

Although in general this film tells the story of the life of the romance of M. Tempel Tarigan, actually the film has a mission that is far deeper than just showing scenes of love and affection. According to Berry Sitepu, commonly called Berry, the producer of JLS, the main mission of the film is to revive the Karo culture and tradition which is fading throughout the time. Berry admitted that the local wisdom of Karo culture and tradition were now in its downfall, where it little by little no longer used in the Karo society. Berry admitted also that it had not been preserved properly throughout the local society. Berry stated that this film JLS, might be a way to remind the society back about these local wisdoms they used to value.

It was obvious that Berry as JLS producer used this film as a transmission medium for Karo culture. According to Porter \& Samovar, formally culture is defined as the order of knowledge, experience, beliefs, values, attitudes, meanings, hierarchy, religion, time, roles, spatial relations, the concept of the universe, material objects and property obtained by a large group of people from generation after generation through individual and group efforts. Culture manifests itself in patterns of language and in forms of activities and behaviors that serve as models for selfadjusting actions and communication styles that allow people to live in a society in a particular geographical environment and at some point in time. Culture also deals with the physical form and structure and social environment that affects our lives [5].

The film JLS shows that the Karo traditions that had not been carried out for a long time were reappointed. Harris \& Moran revealed that tradition was a very important cultural aspect that could be expressed in unwritten habits, taboos, and sanctions. Tradition can influence a nation about what constitutes appropriate behavior and procedures regarding food, clothing, what is valuable, what should be avoided or ignored. Traditions provide people with a "mental order" that has a strong influence on their moral system to judge what is right or wrong, good or bad, pleasant or unpleasant. Traditions express a culture, giving its members a sense of belonging and uniqueness [6].

Based on the explanation above, the authors were interested in making articles as a result of research that discusses the Jandi La Surong film that fulfills one of the functions of mass communication, namely as a cultural transmission medium, in this case, the Karo culture and tradition. Furthermore, in the results section and discussion, this article described and explained why JLS could qualify as a cultural transmission medium for the Karo community.

\section{Method}

Research in article uses qualitative research methods, precisely descriptive-qualitative methods. The descriptive-qualitative method was chosen because the authors gathered facts 
about the Jandi La Surong film (JLS); then afterward described the facts in a model that represented the situation in the field. One of the criteria for descriptive research is to develop concepts and gather facts, accurately describe the characteristics of an individual, circumstances, symptoms, or certain groups [7].

In this research, the authors used data collection techniques in the form of interviews, observations, focus group discussions (FGD), and literature studies. The primary data source of this research was the JLS film crew. Secondary data sources were from books, journals, and websites that discussed JLS films, culture, film, mass communication, and mass media. Purposive procedures were used in the context of taking/selecting informant samples in research. A purposive procedure was carried out by determining groups of participants who were informants according to selected criteria that were relevant to a particular research problem [8]. A purposive procedure was chosen because of the suitability of the informants with the focus of the research. Because this research attempted to reveal the function of JLS films as a Karo cultural transmission media, the informants interviewed and included in the FGD included JLS film producer (Berry Sitepu aka Berry), JLS film director (Creesenda Tenori P. Sembiring aka Ori Semloko), one of JLS film investors (Martha Lina Tarigan aka Lina), and Director of Photography (DoP) JLS film (Roy Manta Sembiring aka Roy).

\section{Result and Discussion}

As mentioned in the introduction, Jandi La Surong (JLS) is a film produced by Karo filmmakers, which tells the story of the love story of M. Tempel Tarigan, one of the characters of Karo, with the girl who became his first love. It was told that Tempel could not keep his promise to the girl. Although wrapped in a love story, JLS's main mission is to introduce and preserve the Karo culture and traditions that are increasingly fading throughout time. Apparently, besides the main mission, this film also carries another mission. Berry (JLS producer) and Ori (JLS director) stated that this film beside reviving Karo culture, traditions and rituals, it was also a form of media for the existence and dignity of the Karo people in general and especially the Karo filmmakers in the midst of all its limitations. Ori added that they also hoped that this film could stimulate the development/creation of other local Karo/North Sumatra films.

JLS is positioned as a film that will be shown in a movie theater, in other words, this film exhibition will later be aimed at playing in theaters. Therefore, technological factors are really calculated in the production phase to post-production. Starting from the tools used in the production process to the software used during the post-film production process. The shift of analog to digital technology also influenced the culture of film production, including the Karo filmmakers. D.o.P JLS (Roy) stated that in terms of technology JLS had followed the format and standard for widescreen films (cinema films). The production equipment with standard cinema technology, for example, cinema cameras, was obtained by renting to a rental place for audio-visual production equipment in Jakarta. This was because no one had ever rented it out in Medan or North Sumatra. The rental price per package per day was 15 million rupiahs. He also stated that it was not enough as camera technology did not meet the standards in JLS production. It would then be anticipated at the post-production stage, precisely in the mastering process. JLS's post-production focused on cutting, while grading and mastering and retouching would be done in Jakarta, at a cost of 150 million rupiahs per film. 


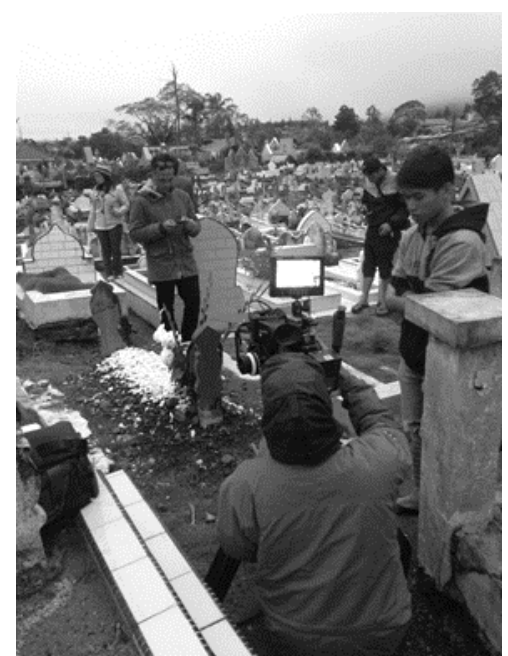

Figure 1. Film production process (shooting) "Jandi La Surong"

Nowadays the majority of film production used are digital tools, both during the production and post-production process. There are almost none filmmakers who produce films with ribbon films. Regarding the technology shift of the film, Vivian said that digital technology seemed to replace the ribbon film. The speed of this transition is difficult to predict. There are technical and financial barriers to digital projections to the big screen, but the benefits of the digital economy are the reason behind the transition to digital. Cameras and editing equipment are easier to use than celluloid film equipment. Delivery of final products on optical discs is also more efficient than using film crates that must be sent to cinema buildings by truck. Even in the projection room, the film reel looks strange. Theoretically, the time will come when digital films can be transmitted via satellite to film projectors in homes, even with central projection controls [2].

In terms of costs and investors, JLS used the crowd funding method with the assistance of the Chairperson of the Karo District Youth and Sports Agency. He also introduced producers to investors. JLS's main investor is M. Tempel Tarigan. After some time, JLS investors finally increased with the entry of Martha Lina Tarigan, or commonly called Lina, an advocate from Karo who lives in Bogor. Lina was interested in becoming one of the JLS investors because she felt that Karo filmmakers had good enthusiasm and motivation to elevate Karo culture and traditions using the film. Lina said that she was glad to see the spirit of of these young Karo children. As a Karonese, she also strongly supported the appointment of Karo culture and tradition in this film, because today's young generation must know that Karo had so much richness in culture and tradition. Lina underlined that it was not a matter of money, but rather on how as a Karonese could help preserve the Karo culture and tradition through this film. Therefore, she decided to become an investor. She also mentioned that it was for the sake of the Karo community as well.

Lina said that she as a Karo person was quite proud and happy to be able to participate in raising and preserving Karo culture and tradition through her role as one of JLS investors. Based on Lina's explanation, JLS could also be said as a film that showed Karo ethnic identity. Collier revealed that ethnicity or ethnic identity originated from inheritance, history, tradition, values, a similarity in behavior, regional origin, and the same language [3]. 
Ethnic identity also comes partly from a language. Language, however, plays a major role in shaping and declaring identity more than imagined. Finegan argues, basically, language is a number of symbols or signs that are agreed to be used by a group of people to produce meaning. The relationship between symbols and agreed-upon meanings sometimes changes [3]. Continuing Finegan's understanding of the meaning of language is a number of symbols, Hayakawa states that among all forms of symbols, language is the most complicated, subtle, and developed symbol [9]. According to Ori and Berry, the language used in JLS was entirely old Karo language, in other words, the Karo language was used in accordance with the setting of this film in the 1960s.

Viewed from the homophilic concept in the context of intercultural communication, the use of Karo language in JLS is the right step, because the segmentation of JLS audience is also for Karo people, then it is likely that the messages that filmmakers try to convey through JLS will be effectively conveyed the audience. The use of Karo language will cause closeness and increase the chance of effective communication that occurs. Schober and Brennan said that when individuals produce messages in the context of social interaction, whether face-to-face or technology-driven contexts, the ability of individuals to coordinate discourse and actions and communicate efficiently is largely determined by the similarity of the background [10].

The use of Karo language on JLS is also one form of preservation of Karo culture. If it is not preserved or used in daily interactions, a language will disappear. This "death of language" also usually becomes the beginning of "cultural death". As Severin \& Tankard reveals, language can disappear because of modern communication, population growth, and migration, all of which accelerates the integration of ethnic groups into larger societies. Linguists mention the reduced impact of intellectual and cultural differences. Generally, a culture dies when a language dies/disappears [11].

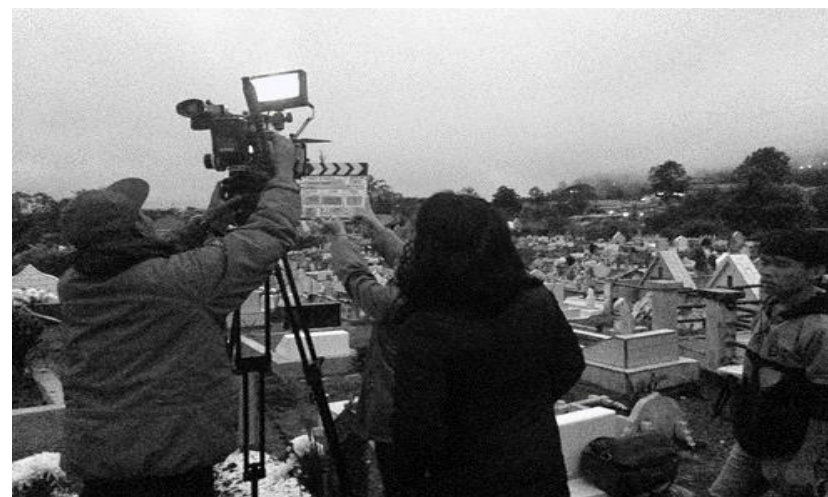

Figure 2. Film production process (out-door shooting) "Jandi La Surong"

JLS is produced as an "answer" to the film 3 Nafas Likas. The film is based on the true story of a character named Likas Tarigan, who was later better known as Likas Gintings, wife of Lieutenant General Djamin Gintings, an Indonesian national hero from Karo, North Sumatra. 3 Nafas Likas told the story of a special woman named Likas, who lived an extraordinary life. Likas then managed to achieve various achievements and success, because she clung to the three promises she had made to the three most important people in her life. Those promises were always in every breath. Breath that had given her spirit and enthusiasm in every action and decision she made. The decision was born on her promise to continue to fight and based on her longing for love [12]. Although it was of Karo background, according to Berry, the film 3 Nafas 
Likas did not fully describe Karo culture but focused more on describing the political atmosphere in Indonesia in the year involving Djamin Gintings, husband of Likas. Roughly, 3 Nafas Likas only used the Karo set, but it was not aimed to preserve the culture.

The social reality about Karo that was meant to be constructed by the film 3 Nafas Likas, was then reconstructed by JLS by bringing out the Karo culture and tradition in more details. The term construction of social reality became famous since it was introduced by Peter L. Berger and Thomas Luckmann through his book entitled The Social Construction of Reality: A Treatise in the Sociological of Knowledge (1966). He described social processes through their actions and interactions, where individuals create continuously a reality that was owned and experienced jointly subjectively [13]. Regarding the construction of social reality by the media, Carey revealed that the media might reflect the world, but they also produced the world [14]. And, when individuals interact with the media, they adore the way society replaces their sense of world as a different world that is the projection of ideas created by the community.

JLS displayed scenes that were thick with Karo culture and tradition. There are dances, interaction rituals, up to sports activities and traditional Karo martial arts. Berry stated that some Karo cultures and rituals presented in JLS include the Bertutur tradition (introduction of young people), Erpangir Ku Lau, Gundala-gundala (a kind of mask dance), Ndikar (silatKaro), Satur (Karo chess), Karo traditional house, Karo culinary, and Karo artifacts.

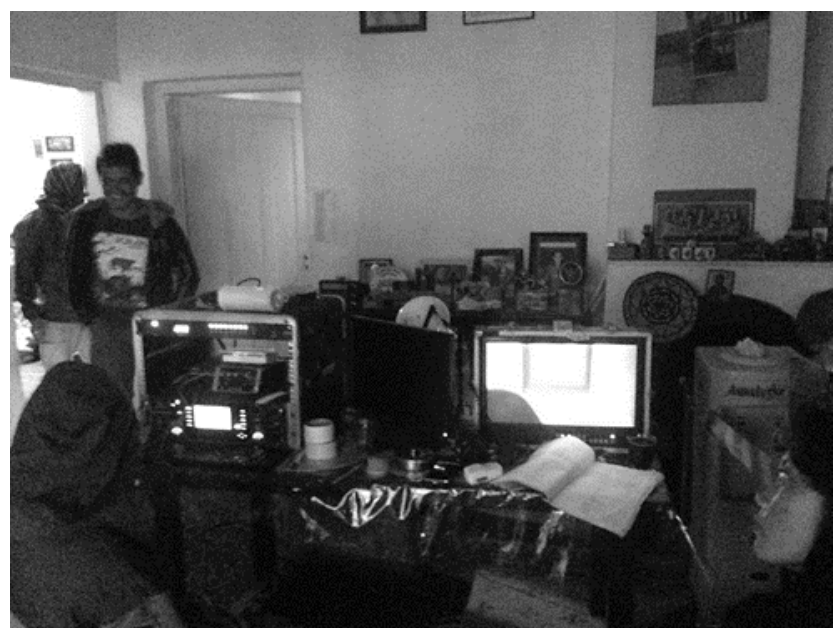

Figure 3. Film production process (in-door shooting) "Jandi La Surong"

This Bertutur tradition is still running in the Karo community and for two Karo people who have met overseas are often acquainted with explaining Marga or Beru and their Bere-bere. The Karo people who can explain their speech well can change their acquaintance status to become a Senina or Kalimbubu depending on the Marga. In the Karo community, such people are considered smart to speak and associate and are respected because they are considered capable of Karo worship [15]. Whereas Erpangir Ku Lau is a ritual bathing/washing hair in the Karo community to launch certain goals. For Satur, the difference lies in the rules of the game, the pieces, and the chessboard. Gundala-gundala is a dance performed with the intention of calling rain during the dry season, where the dancers use wooden masks. Ndikar is like Pencak, the goal for entertaining dances when Silat is not being demonstrated. Swordsman needs the distribution of energy, therefore the Pencak is born, all of whose movements are Silat. Then it is called Pencak Silat. Like most martial arts shows. Traditional musical accompaniment to add 
a deep impression to the knowledge in learning Silat. Pencak in Karonese Silat (Ndikar) is included in "Tari-tari Bintang"[16].

The Karo culture and tradition presented in JLS can also reunite the Karo people because of their ethnic similarity background. This is called the function of creating a sense of unity. The function of mass communication that is not much realized by all of us is its ability to make us feel a member of a group [1]. JLS is also one of the manifestations of social heritage. Submission of social heritage is a function in which the media convey information, values, and norms from one generation to the next or from community members to migrants. In this way, they aim to increase community unity by expanding the basis of their general experience [11].

\section{Conclusion}

The Jandi La Surong (JLS) film is one of the regional films produced by Karo filmmakers who tells us about the romance story of M. Tempel Tarigan in a 1960 setting. More than that, actually the main mission of JLS is to become a Karo cultural transmission media. This can be seen from the use of the Karo language in JLS, as well as the display of various Karo cultures and traditions in JLS, such as Bertutur, Erpangir Ku Lau, Gundala-gundala, Ndikar, Satur, and some of Karonese artifacts. In addition to having a mission to preserve and revive Karo culture, JLS has also become a form of media for the existence and dignity of the Karo community and is expected to stimulate the development of local films in North Sumatra.

\section{Acknowledgment}

We express our sincere gratitude to JLAS Production, especially to Berry Sitepu (JLS producer), Creesenda Tenori P. Sembiring (JLS director), Martha Lina Tarigan (JLS investor), and Roy Manta Sembiring (JLS Director of Photography) for interviewing time, observation and the FGD opportunity that has been given. We also thank to our colleagues at Padjadjaran University who have provided criticisms and suggestions for this article.

\section{References}

[1] E. Ardianto, L. Komala, and S. Karlinah, Komunikasi Massa: Suatu Pengantar. Bandung: Simbiosa Rekatama Media, 2007.

[2] J. Vivian, Teori Komunikasi Massa, 8th ed. Jakarta: Prenadamedia Group, 2015.

[3] L. A. Samovar, R. E. Porter, and E. R. McDaniel, Komunikasi Lintas Budaya, 7th ed. Jakarta: Salemba Humanika, 2014.

[4] Morissan, Teori Komunikasi: Individu Hingga Massa. Jakarta: Prenadamedia Group, 2014.

[5] R. E. Porter and L. A. Samovar, "Suatu Pendekatan Terhadap Komunikasi Antarbudaya," in Komunikasi Antarbudaya: Panduan Berkomunikasi dengan Orang-orang Berbeda Budaya, Bandung: Remaja Rosdakarya, 2006, pp. 11-35.

[6] P. R. Harris and R. T. Moran, "Memahami Perbedaan-perbedaan Budaya," in Komunikasi Antarbudaya: Panduan Berkomunikasi dengan Orang-orang Berbeda Budaya, Bandung: Remaja Rosdakarya, 2006, pp. 54-71.

[7] A. Bajari, Metode Penelitian Komunikasi: Prosedur, Tren, dan Etika. Bandung: Simbiosa Rekatama Media, 2015.

[8] B. Bungin, Penelitian Kualitatif: Komunikasi, Ekonomi, Kebijakan Publik, dan Ilmu Sosial Lainnya. Jakarta.: Kencana, 2011. 
[9] S. I. Hayakawa, "Simbol-simbol," in Komunikasi Antarbudaya: Panduan Berkomunikasi dengan Orang-orang Berbeda Budaya, Bandung: Remaja Rosdakarya, 2006, pp. 96-104.

[10] C. R. Berger, "Proses Produksi Pesan," in Handbook Ilmu Komunikasi, Bandung: Nusa Media, 2015, pp. 157-180.

[11] W. J. Severin and J. W. Tankard, Teori Komunikasi: Sejarah, Metode, dan Terapan di Dalam Media Massa. Jakarta: Prenadamedia Group, 2008.

[12] “3 Nafas Likas.”.

[13] B. Bungin, Konstruksi Sosial Media Massa. Jakarta: Prenadamedia Group, 2011.

[14] D. Holmes, Teori Komunikasi: Media, Teknologi, dan Masyarakat. Yogyakarta: Pustaka Pelajar, 2102.

[15] A. Imanuel, "Tradisi Tutur Siwaluh Suku Karo," 2018. .

[16] S. R. Saleh, "Silat Karo, 'Jurus Matahari Terbenam,"” 2015. . 